К ЧИТАТЕЛЯМ

\section{НАУЧНО-АНАЛИТИЧЕСКОГО ЖУРНАЛА «ТРУДЫ ПО ИНТЕЛЛЕКТУАЛЬНОЙ СОБСТВЕННОСТИ»}

Григорий Петрович ИВЛИЕВ,

руководитель Федеральной службы

по интеллектуальной собственности (Роспатент)

(Москва, Россия, rospatent@rupto.ru)

DOI: https://doi.org/10.17323/tis.2021.13233
- MESSAGE TO READERS

- OF THE "WORKS ON

- INTELLECTUAL PROPERTY"

- QUARTERLY

- Grigoriy P. IVLIEV,

Chief of the Federal Service for

- Intellectual Property (ROSPATENT) (Moscow, Russia,

- rospatent@rupto.ru) DOI: https://doi.org/10.17323/

- tis.2021.13233

Уважаемые комеги!

Все более очевидно, что в настоящее время интемлектуальная собственность становится инструментом, стимулирующим не только научно-технический прогресс, но и все развитие общества - экономическое, социальное, культурное. ПредсеАатель правительства Российской Федерации Михаил Мишустин не раз отмечал, что защита прав интемлектуальной собственности должна быть приоритетом.

В современную эпоху роль интемлектуальной собственности последовательно возрастает. ГАавный вызов 2020 г. - пандемия COVID-19 - показал колоссальную значимость сфер, опредемяющих безопасность и качество жизни человека. Преодоление этого вызова стало возможным в том числе благодаря работе Роспатента, стимулирующего инновационные подходы при созАании среАств Аля борьбы с коронавирусной инфекцией. В 2020 г. Россия первой в мире запатентовама вакцину «Спутник V».

Современная экономическая ситуация не только в Российской Федерации, но и во всем мире развивается в ключе всеобщей цифровизации производственных процессов и взаимодействия межАу компаниями, индивидуальными преАпринимателями и иными участниками рыночных отношений как между собой, так и с федеральными органами государственной вмасти.

Россия подАерживает актуальные мировые тенденции цифровизации сферы интемлектуальной собственности, отраженные в приоритетах развития Всемирной организации интемеектуальной собственности (ВОИС). Роспатент не просто аАаптируется к изменениям, происходящим в области науки и технологий, но и выступает Арайвером трансформационных процессов в сфере интемлектуальной собственности. Российская Федерация преАсеАательствует в Целевой группе по трехмерным (3D) моделям и изображениям, а также явцяется сопреАсеАателем Цемевой группы по блокчейн-технологиям Комитета по стандартам ВОИС. Роспатент активно внеАряет в своей работе искусственный интемлект, опираясь на запросы общества и бизнеса, а также на современные тенденции развития интелмектуальной собственности.

В рамках реализации национальной программы «Цифровая экономика Российской Федерации» уже работают в тестовом режиме поисковая платформа Роспатента, ГИС «Распределенный реестр прав на объекты интемлектуальной собственности и среАства индивидуализации, находящиеся в обороте», ГИС «Экспертиза среАств индивидуализации», ГИС «ПоААержка управленческих решений». Они созАаны на базе российского программного обеспечения и призваны повысить эффективность работы веАомства, улучшить условия Аля исслеАовательской и преАпринимательской Аеятельности. Всего планируется внеАрить 11 государственных информационных 
систем, четыре информационные системы, семь обеспечивающих программно-аппаратных комплексов и одну обеспечивающую информационную систему.

В современных условиях сфера интелмектуальной собственности продолжает развиваться. В процессе правоприменительной практики выявмяются новые потребности в Аетализации правового регулирования. Кроме того, в эпоху глобализации усиливается тенденция гармонизации правового регулирования, которая связана как с использованием зарубежного опыта при разработке изменений национального законодательства, так и с развитием глобальных и региональных систем регистрации интемлектуальной собственности.

В настоящее время ведется работа по формированию евразийского механизма ААя получения правовой охраны товарных знаков и наименований места происхожАения товара (НМПТ). Завершена ратификация Протокола об охране промышиенных образцов к Евразийской патентной конвенции (ЕАПК). Евразийская система правовой охраны промышленных образцов расширит охват Евразийской патентной системы, позволит сократить временные, финансовые и административные издержки заявителей.

Амя упрощения доступа российским заявитемям, а также Аля расширения Аоступа русскоязычным заявитемям из стран ближнего зарубежья к межАународным инструментам регистрации прав выАвинута инициатива по включению русского языка в качестве официального в рамках Мадридской системы межАународной регистрации товарных знаков и Гаагской системы межАународной регистрации промышиенных образцов.

Подготовцен законопроект о присоединении России к Женевскому акту Аиссабонского соглашения о наименованиях мест происхождения и географических указаниях. Роспатент будет компетентным ведомством от Российской Федерации, принимающим заявки на межАународную регистрацию НМПТ и географических указаний.

Роспатент занимает одну из кАючевых позиций в подготовке нормативных правовых актов в сфере интемкектуальной собственности и выступил с рядом важнейших инициатив. Механизм управления системными изменениями предпринимательской среды «Трансформация делового кмимата» явмяется одним из ориентиров в совершенствовании деятельности Роспатента с учетом вызовов цифровой экономики. Премьер-министр Российской Федерации Михаил Мишустин неАавно отметил, что «благодаря этим и другим решениям правительства инвестиционная привлекательность нашей страны, несмотря на пандемию, непростую ситуачию на сырьевых рынках, продољжает повышаться).

Аорожная карта совершенствования охраны интемлектуальной собственности, разработанная Роспатентом в качестве документа стратегического планирования, предусматривает ряд изменений в ГК РФ и ряА Аругих актов, направленных на повышение качества государственных и коммерческих услуг в сфере интемлектуальной собственности, предоставление новых возможностей Аля патентования разработок, использование интемлектуальной собственности аля развития бизнеса и продвижения товаров.

Кроме того, ведомство подАерживает реализацию мер по устранению измишних налоговых барьеров.

По инициативе Роспатента быц принят Федеральнный закон от 31 января 2020 г. № 262-Ф3 «О внесении изменений в часть четвертую ГражАанского коАекса Российской Федерации». Аокумент внес в ГК РФ существенные изменения, предусматривающие привцечение аккредитованных Роспатентом организаций к проведению преАварительных информационного поиска и оценки патентоспособности в рамках экспертизы заявок на изобретения и полезные модели. В условиях непрерывного технического прогресса, усложнения технической сущности заявмяемых решений и возрастания объема информации, включаемой в уровень 
техники, Аанное решение позволит предотвратить увеличение сроков рассмотрения заявок, повысить качество (надежность) патента за счет привлечения отраслевых специалистов.

Благодаря подАержке Совета Федерации и Минэкономразвития России был принят Закон о географических указаниях, который становится Аейственным и эффективным рычагом Аля развития экономики регионов и местных товаропроизвоАителей.

Вступление в силу с 17 января 2021 г. Закона о трехмерных модемях способствует сокращению сроков проводимой экспертизы изобретений, полезных моделей, промышленных образцов, товарных знаков и повышению ее качества. Трехмерные модели позволяют упростить процеАуру подачи заявок заявителем, использующим 3D-технологии при проектировании и моделировании объектов, что удовлетворит потребности крупных корпораций, инжиниринговых центров, высокотехнологичных производств, стартапов.

Кроме того, получение охранных Аокументов в электронном виАе исключает временны́е затраты на их отправку по почте и позволяет полностью перевести взаимодействие с заявителями в электронный виА, что соответствует современным тенденциям модернизации государственных услуг в Российской Федерации.

Ключевыми факторами успешной коммерциализации собственных разработок становятся патентная аналитика и патентные исследования. Роспатент развивает инструментацьные методы патентной анацитики, разрабатывает новые продукты и сервисы Аля широких областей применения — как в интересах государства, так и в интересах бизнеса, отраслевых ассоциаций. Производственные процессы консалтинга на базе патентной аналитики сертифицированы по международной системе управления качеством ГОСТ Р ИСО 9001-2015 (ISO 9001-2015). Потребность бизнеса в патентной аналитике очевидна. Именно она позволяет выявцять наилучшие Аоступные технологии, новые области применения продукции, оценивать конкурентоспособность российских технологий и анализировать стратегии вывода продукции на рынок.

В 2021 г. переА веАомством стоит задача достичь уровня подачи заявок на регистрацию объектов интемлектуальной собственности в электронном виде Ао 75 \%. Серьезное достижение ведомства - существенное сокращение сроков рассмотрения заявок по всем объектам интемектуамьной собственности.

УбежАен, что все перечисленные приоритеты будут содействовать эффективному развитию сферы интемлектуацьной собственности, совершенствованию гражАанского законодательства и созАанию комфортной клиентоориентированной среды Аля изобретательского и преАпринимательского сообщества, а также эффективному решению задачи по наращиванию патентной активности и выходу нашей страны в топ-5 мировых мидеров.

В этом номере журнала «Труды по интемлектуацьной собственности», как и в преАыдущем, публикуются научные статьи, подготовленные на основе АоклаАов, прозвучавших в апреме 2021 г. на первой межАународной научно-практической конференции «Авторско-правовые проблемы в сфере промышленной собственности», которая быма организована Роспатентом совместно с КафеАрой ЮНЕСКО по авторскому праву, смежным, культурным и информационным правам НИУ «Высшая школа экономики» и Российским авторским обществом при организационной и научной поААержке ФеАерального института промышиенной собственности. Мы рассчитываем, что этот форум, собравший видных ученых-правоведов, специамизирующихся в области авторского права, смежных прав, патентного права и т.А., станет ежегодным, приуроченным ко Всемирному Аню книги и авторского права (23 апреля; провозглашен Генеральной конференцией ЮНЕСКО в 1995 г.) и МежАународному Аню интемлектуальной собственности (26 апреля; учрежАен Генерамьной ассамблеей ВОИС в 2000 г.). 